\title{
Jubileusz 70-lecia Archiwum Uniwersytetu Mikołaja Kopernika w Toruniu (18-19 października 2018 r.)
}

Weronika Krajniak

Toruń

16 września 2018 r. minęło siedemdziesiąt lat od momentu powołania do życia Archiwum Uniwersytetu Mikołaja Kopernika w Toruniu. Z tej okazji archiwiści uniwersyteccy w ciągu całego roku promowali zasób i jednostkę. Na portalu społecznościowym facebook można obejrzeć krótki cykl „Spacer po archiwum”, autorstwa mgr. Jacka Waliszewskiego. „Spacer” miał przybliżyć pomieszczenia i zakamarki magazynów archiwalnych. Z inicjatywy mgr. Waliszewskiego, przy współpracy z Sekcją Filmową UMK, powstał też krótki klip, który można obejrzeć na fanpage'u Archiwum. Rok jubileuszowy to także rok zmian. Kierownik Archiwum dr hab. Anna Supruniuk upamiętniła poprzednich kierowników, tworząc galerię ich portretów w pomieszczeniach Archiwum, a także zredagowała folder informacyjny o jednostce. Największym jednak przedsięwzięciem pracowników: mgr Bożeny Kierzkowskiej, mgr Weroniki Krajniak, dr hab. Anny Supruniuk i mgr. J. Waliszewskiego było przygotowanie publikacji pt. Archiwum Uniwersytetu Mikołaja Kopernika w Toruniu. Informator o zasobie archiwalnym, pod redakcją A. Supruniuk i W. Krajniak. Promocja wydawnictwa odbyła się podczas obchodów jubileuszowych, zaplanowanych na 18-19 października br. Uroczystości zorganizowano w Sali Senatu Collegium Maximum przy pl. Rapackiego 1. W przeddzień pracownicy Archiwum UMK na cmentarzu św. Jerzego złożyli kwiaty i zapalili znicze na grobach byłych kierowników oraz prof. Ludwika Kolankowskiego, pierwszego rektora UMK.

W pierwszym dniu uroczystości, zorganizowanej pod patronatem JM Rektora UMK prof. Andrzeja Tretyna, Naczelnego Dyrektora Archiwów Państwo- 


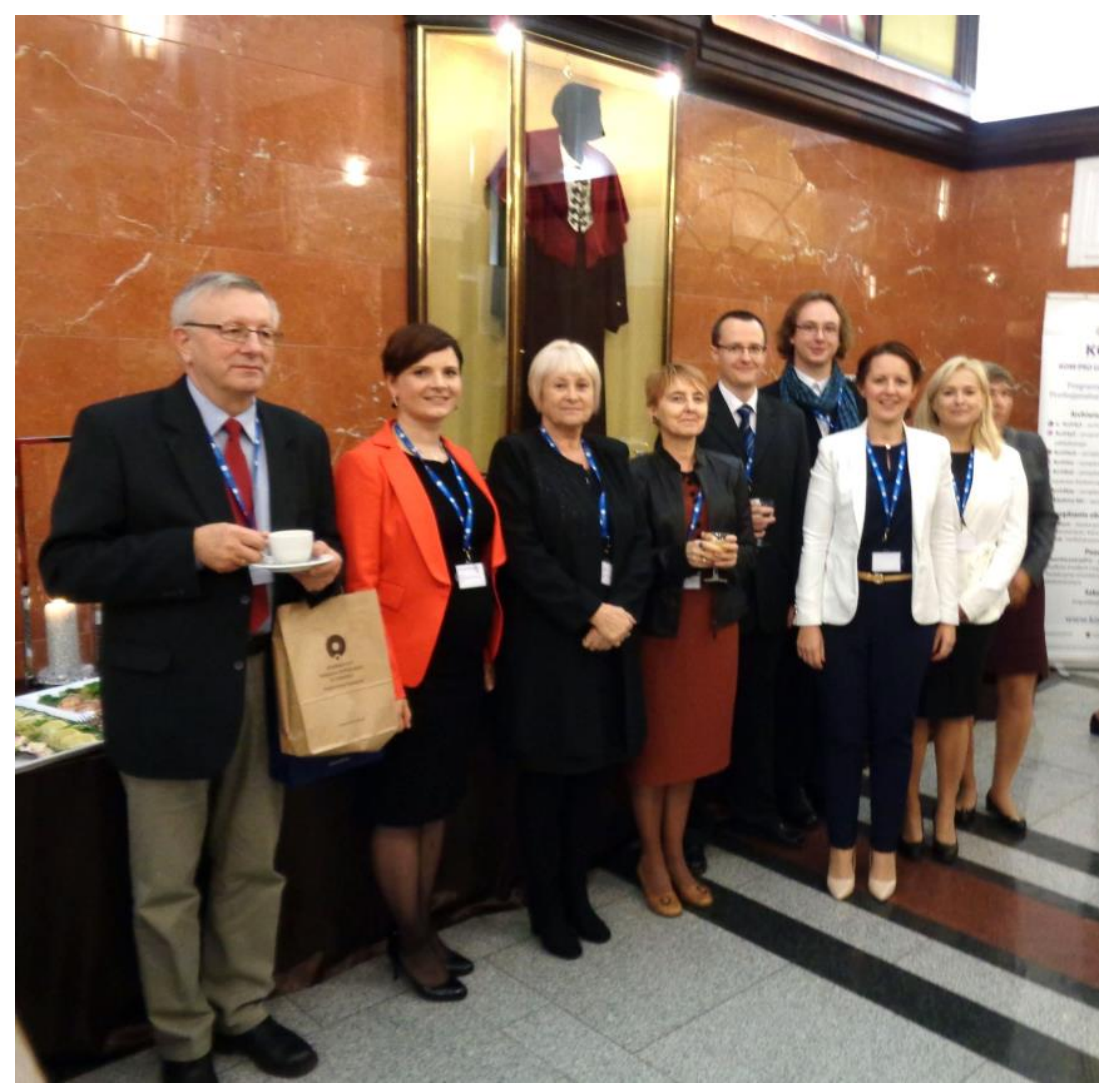

Pracownicy Archiwum UMK

Od lewej: mgr E. Pazderski, dr P. Bunkowska, G. Gnich, dr hab. A. Supruniuk, mgr J. Waliszewski, mgr A. Wójtowicz, mgr W. Krajniak, mgr B. Kierzkowska, T. Gałka

wych dr. Wojciecha Woźniaka i dziekana Wydziału Nauk Historycznych UMK prof. Stanisława Roszaka, odbyło się spotkanie z udziałem gości, sympatyków i przyjaciół jednostki. Na początku został wyświetlony klip promujący Archiwum UMK. Następnie dr hab. Anna Supruniuk dokonała uroczystego otwarcia obchodów, podziękowała wszystkim za przybycie, a także wspomniała pierwszych organizatorów i „sprawców” powołania do życia Archiwum, po czym 
głos oddała zaproszonym gościom, którzy m.in. odczytali adresy gratulacyjne. W imieniu JM Rektora UMK wystąpiła mgr Justyna Morzy, kanclerz Uniwersytetu, która dziękowała za dobrą współpracę i opiekę nad komórkami administracji, a także podkreśliła ważną rolę, jaką odgrywa Archiwum w Uczelni. Następnie głos zabrali m.in.: prof. dr hab. Zbigniew Witkowski, dziekan Wydziału Prawa i Administracji (WPiA), który na ręce kierownika Archiwum przekazał Srebrny Medal Honorowy WPiA UMK, prof. dr hab. Stanisław Roszak, dziekan Wydziału Nauk Historycznych (WNH), dr Magda Gałach, dyrektor Departamentu Kształtowania Narodowego Zasobu Archiwalnego Naczelnej Dyrekcji Archiwów Państwowych (NDAP), dr hab. Krzysztof Kopiński, prof. UMK, zastępca dyrektora Instytutu Historii i Archiwistyki WNH UMK, byli członkowie Rady Archiwum UMK: prof. dr hab. Włodzimierz Karaszewski z Wydziału Nauk Ekonomicznych i Zarządzania UMK i prof. dr hab. Andrzej Radzimiński z WNH, mgr Jakub Paprotny, sekretarz Sekcji Instytucji Naukowych i Kulturalnych Stowarzyszenia Archiwistów Polskich, mgr Anna Bieniek, kierownik Archiwum Uniwersytetu Śląskiego w Katowicach, mgr Ewa Kłapcińska, kierownik Oddziału Materiałów Archiwalnych Archiwum Uniwersytetu Wrocławskiego, mgr Anna Domalanus, kierownik Archiwum Uniwersytetu im. Adama Mickiewicza, mgr Joanna Stasiak, pracownik Archiwum Polskiej Akademii Nauk w Warszawie i dr Cecylia Iwaniszewska, emerytowany pracownik UMK, od lat zaprzyjaźniona z jednostką.

Pracownicy Archiwum podziękowali obecnej kierownik dr hab. A. Supruniuk za dotychczasową współpracę, a także wręczyli kwiaty obecnym na sali byłym pracownikom.

Następnie odbyła się promocja wydawnictwa zatytułowanego Archiwum Uniwersytetu Mikołaja Kopernika w Toruniu. Informator o zasobie archiwalnym. Dr hab. K. Kopiński zaprezentował książkę i jej strukturę oraz podkreślił znaczenie publikacji dla użytkowników i prowadzenia badań naukowych.

W końcowej części spotkania odbył się pokaz wystawy multimedialnej autorstwa mgr W. Krajniak pt. „Prywatne archiwa kierowników Archiwum Uniwersytetu Mikołaja Kopernika w Toruniu”. Ekspozycja powstała przy współpracy z Sekcją Filmową UMK.

Ostatnim punktem tego dnia była uroczysta kolacja, w której udział wzięli zaproszeni goście.

W kolejnym dniu odbyła się ogólnopolska konferencja pt. „Archiwa uczelniane w dobie elektronicznego zarządzania dokumentacją". Jej organizatorkami były dr Paulina Bunkowska i mgr B. Kierzkowska. Sesję otworzyły dr hab. A. Supruniuk oraz prof. dr hab. Danuta Dziawgo, prorektor ds. ekonomicznych i rozwoju UMK, która podkreśliła rozwój i „zaistnienie” jednost- 
ki w środowisku naukowym za kierownictwa A. Supruniuk. Po czym ponownie wyświetlono klip promujący Archiwum UMK. Następnie głos oddano moderatorowi obrad dr hab. K. Kopińskiemu, który po przywitaniu prelegentów i uczestników konferencji zaprosił pierwszego z nich, prof. dr. hab. Władysława Stępniaka, emerytowanego pracownika UMK, do wygłoszenia referatu nt. „Archiwa uniwersyteckie w świetle polityki UNESCO wobec dziedzictwa kulturowego". W swoich rozważaniach mówca przypomniał słowa prof. Sławomira Kalembki o znaczeniu archiwów uniwersyteckich, które zabezpieczają dziedzictwo uczelniane. Referent swoją wypowiedź oparł na konwencjach i dyrektywach UNESCO, począwszy od wydanej w 1972 r. w sprawie ochrony światowego dziedzictwa kulturalnego i naturalnego, a skończywszy na zaleceniach UNESCO z 2015 r. w sprawie zachowania i dostępu do dziedzictwa dokumentacyjnego, w tym dziedzictwa cyfrowego.

Kolejne wystąpienie dotyczące „RODO w archiwach uczelnianych”, w zastępstwie mgr Joanny Dziadkowiec, wygłosiła mgr Marzena Mrozińska z firmy KOM-PRO. Wypowiedź rozpoczęła od omówienia podstawowych definicji, takich jak dane osobowe, administrator, w świetle rozporządzenia Parlamentu Europejskiego i Rady Europejskiej z dnia 27 kwietnia 2016 r. „w sprawie ochrony osób fizycznych w związku z przetwarzaniem danych osobowych i w sprawie swobodnego przepływu takich danych oraz uchylenia dyrektywy 95/46/W". Następnie wskazała formy zabezpieczenia fizycznego i informatycznego oraz sposoby ochrony przed incydentami i zdarzeniami.

Wystąpienie dr Magdy Gałach z NDAP odnosiło się do „Archiwum Dokumentów Elektronicznych, czyli co dalej z materiałami archiwalnymi w postaci elektronicznej". Punktem wyjścia tych rozważań był różnie zapisany w przepisach prawnych termin dokumentu elektronicznego. Następnie prelegentka zreferowała wymagania, jakie powinny spełniać systemy EZD. Zaprezentowała także fragment systemu e-DOK, który jest używany w NDAP. Na zakończenie swojej wypowiedzi omówiła projekt Archiwum Dokumentów Elektronicznych oraz podała powody podjęcia działań i zakres tego przedsięwzięcia. Po referacie nastąpiła ożywiona dyskusja dotycząca głównie ochrony danych osobowych. Głos w niej zabrali m.in.: K. Kopiński, M. Gałach, M. Mrozińska, E. Kłapcińska i mgr Sławomir Pułkownik, zastępca dyrektora Archiwum Państwowego w Toruniu.

Po przerwie głos oddano mgr Kamili Latosze, kierownikowi Kancelarii Ogólnej Uniwersytetu Szczecińskiego, która opowiedziała o „Początkach działalności koordynatora czynności kancelaryjnych na Uniwersytecie Szczecińskim". Referentka omówiła po kolei zakres działań koordynatora, który na początku polegał na weryfikacji dokumentacji poszczególnych jednostek 
uczelnianych, a następnie na nauce prawidłowego klasyfikowania i kwalifikowania akt.

Wystąpienie mgr Anny Bieniek, kierownika Archiwum Uniwersytetu Śląskiego w Katowicach, dotyczyło „Roli archiwum szkoły wyższej w planowaniu procesu wdrażania elektronicznego zarządzania dokumentacją". Prelegentka wyszczególniła etapy przygotowań tej uczelni do wdrożenia EZD oraz zaznaczyła napotykane problemy wynikające niekiedy z innego pojmowania terminu dokumentacji przez archiwistów i informatyków.

Ostatni, przed przerwą, referat o „Astronomie w archiwum” wygłosił mgr Eugeniusz Pazderski, emerytowany pracownik UMK. Jego wypowiedź dotyczyła baz powstałych w końcu lat 90 . XX w. w Archiwum UMK, m.in.: Absolwent, Biogramy czy Bazy Osób Zmarłych.

Po przerwie wysłuchano wystąpienia dr Ewy Kurkowskiej, uczelnianego koordynatora ds. elektronicznego zarządzania dokumentacją UMK, które dotyczyło „Elektronicznego Zarządzania Dokumentacją (EZD) w Uniwersytecie Mikołaja Kopernika w Toruniu”. Prelegentka nakreśliła w nim zakres działań koordynatora i zespołu ds. wdrażania elektronicznego systemu obsługi dokumentacji.

W dyskusji po tym referacie głos zabrali: dr P. Bunkowska, koordynator czynności kancelaryjnych UMK, dr Tomasz Jędrzejewski, zastępca kanclerza ds. administracyjnych UMK, i mgr E. Kłapcińska. Całość obrad podsumował $\mathrm{dr}$ hab. K. Kopiński, który zauważył, że w związku z wprowadzaniem w uczelniach EZD archiwa uniwersyteckie w niedalekiej przyszłości czekają duże wyzwania. Podziękowania za udział w obradach i uroczystościach jubileuszowych w imieniu kierownika Archiwum UMK złożyła dr P. Bunkowska. 